\title{
KOLABORASI DAN PRODUKTIVITAS PENULIS ARTIKEL VISI PUSTAKA 2000 - 2014
}

\author{
Rochani Nani Rahayu ${ }^{1)^{*}}$ dan Rulina Rachmawati ${ }^{2)}$ \\ ${ }^{122)}$ Pustakawan Pusat Dokumentasi dan Informasi Ilmiah - LIPI \\ *Korespondensi: nanipdii@yahoo.com
}

\begin{abstract}
Visi Pustaka is one of the Library and Information Science (LIS) journals in Indonesia. Study about this journal needs to be done to find out the progress in Library and Information Science in Indonesia. This paper reviewed Visi Pustaka journal especially about the amount of articles, gender, collaboration degree, collaboration frequency, productivity, and author affiliation. Data collected from Visi Pustaka journal articles which published in 2000-2014 periods. Data analyzed using statistic descriptive method. The result showed that the amount of article published in 2000-2014 periods were 236 articles, about $65.64 \%$ written by men and $34.36 \%$ written by women. Average degree of collaboration was 0.097. The most productive authors were Sulistyo Basuki and B. Mustafa. Both of them submitted 16 articles. The most five productive affiliation were Bogor Institute of Agriculture (14.38\%), Indonesian National Library (11.45\%), Indonesian University (12.60\%), Centre for Scientific Documentation and Information (8.02\%) and Gadjah Mada University (6.11\%). The affiliation status consisted of 212 (80.91\%) government institutions and 50 (19.09\%) was private organizations. We cloncluded that most gender of author was men, most of the articles wrote by individual authors, and most author affiliations were library and information institutions also universities.
\end{abstract}

\begin{abstract}
ABSTRAK
Visi Pustaka merupakan salah satu jurnal bidang Ilmu Perpustakaan dan Informasi (IPI) di Indonesia yang terbit sejak tahun 2000. Kajian terhadap jurnal ini penting dilakukan untuk mengetahui perkembangan IPI di Indonesia. Aspek yang dikaji meliputi jumlah artikel, jenis kelamin penulis, tingkat kolaborasi, frekuensi kolaborasi, produktivitas, dan afiliasi penulis. Metode pengumpulan data dilakukan terhadap artikel yang terbit pada Jurnal Visi Pustaka tahun 2000-2014. Data dianalisis menggunakan metode secara statistik deskriptif. Hasil menunjukkan bahwa jumlah artikel dari tahun 2000-2014 sebanyak 236 artikel. Sebanyak 65,64\% ditulis oleh laki-laki dan 34,36\% ditulis oleh perempuan. Tingkat kolaborasi rata-rata sebesar 0,097. Pengarang yang paling produktif adalah Sulistyo Basuki dan B. Mustafa dengan jumlah artikel sebanyak 16 artikel. Dijumpai 5 besar instansi penyumbang artikel berturut-turut adalah Institut Pertanian Bogor (14,38\%), Perpustakaan Nasional Republik Indonesia (11,45\%), Universitas Indonesia (12,60\%), Pusat Dokumentasi dan Informasi Ilmiah (8,02\%), Universitas Gadjah Mada (6,11\%). Afiliasi yang berstatus negeri $80,91 \%$ dan swasta 19,09\%. Disimpulkan bahwa penulis laki-laki lebih banyak dibandingkan dengan penulis perempuan, sebagian besar artikel ditulis secara individu, afiliasi penulis terbanyak berasal dari instansi bidang perpustakaan dan informasi serta perguruan tinggi.
\end{abstract}

Keywords: Writers; Employee productivity; Journal writing; Periodicals; Library science; Visi Pustaka

\section{PENDAHULUAN}

Komunikasi ilmiah untuk menyebarluaskan hasil-hasil penelitian, ide serta hal-hal lain yang berkaitan dengan ilmu informasi dan perpustakaan salah satunya dapat dilakukan melalui Jurnal Visi Pustaka adalah salah satu terbitan berkala berisikan tentang ilmu informasi dan perpustakaan yang diterbitkan oleh Perpustakaan Nasional Republik Indonesia.

Visi Pustaka hingga saat ini belum mendapatkan status terakreditasi secara nasional. Adanya persyaratan akreditasi dimaksudkan untuk menjaga kualitas majalah secara umum dan secara khusus adalah kualitas dari artikel yang dimuat di dalamnya. Indikator kualitas suatu artikel diantaranya adalah penulis, kolaborasi penulis, dan instansi tempat penulis bekerja (afiliasi). Belum adanya kajian 
mengenai jumlah artikel, maupun tingkat kolaborasi penulis dari artikel yang dimuat dalam Jurnal Visi Pustaka dari tahun 2000 - 2014, mendorong dibuatnya suatu analisis mengenai hal tersebut.

Kajian ini bertujuan untuk mengetahui jumlah artikel, jumlah dan jenis kelamin penulis artikel, tingkat kolaborasi penulis, frekuensi kolaborasi penulis, peringkat produktivitas penulis, instansi tempat bekerja penulis, yang artikelnya dipublikasikan pada Jurnal Visi Pustaka periode tahun 2000 - 2014.

\section{TINJAUAN PUSTAKA}

\subsection{Terbitan Visi Pustaka}

Visi Pustaka adalah terbitan berkala bidang dokumentasi, informasi, dan perpustakaan yang diterbitkan oleh Perpustakaan Nasional Republik Indonesia sejak Oktober 1999. Visi Pustaka terbit dengan frekuensi enam bulan sekali dengan kode ISSN 1411-2256.

Visi Pustaka merupakan majalah yang sudah menginjak dewasa mengingat majalah tersebut sudah diterbitkan pertama kali pada Oktober 1999, sehingga sampai dengan 2015 majalah tersebut berusia 16 tahun. Pada awalnya, Visi Pustaka diterbitkan sebanyak 2 kali dalam setahun, namun sejak tahun 2007 frekuensi terbit majalah tersebut bertambah menjadi tiga kali dalam setahun yaitu pada April, Agustus, dan Desember. Hal ini menunjukkan bahwa semakin banyak penulis yang aktif berbagi pengetahuan dengan cara mengkomunikasikan atau menyebarluaskan hasil pemikirannya, baik berupa hasil penelitian, ide, maupun hal-hal lain yang berkaitan dengan ilmu informasi dan perpustakaan melalui terbitan Visi Pustaka.

\subsection{Kolaborasi Penulis}

Kolaborasi penulis dapat menggambarkan adanya tingkat kesulitan suatu penelitian dari suatu subjek tertentu. Sutarsyah (2014), menjelaskan beberapa keuntungan yang diperoleh bila penulis berkolaborasi. Kolaborasi antar-penulis memungkinkan adanya kesempatan berbagi pengetahuan, keahlian, dan teknik tertentu dalam sebuah ilmu. Selain itu, kolaborasi peneliti dari berbagai latar belakang keahlian dapat memecahkan permasalahan kompleks sehingga dapat menghasilkan karya ilmiah dengan kualitas yang lebih baik.

Beberapa studi tentang kolaborasi penulis yang dicerminkan dari pola kepengarangan khususnya di bidang ilmu perpustakaan dan informasi (IPI) sudah banyak dilakukan, beberapa diantaranya diuraikan pada Tabel 1.

Tabel 1. Penelitian Kolaborasi Penulis Terdahulu

\begin{tabular}{|c|c|c|c|c|}
\hline No. & Penulis / Peneliti & Tahun & Judul & Hasil Penelitian \\
\hline 1 & $\begin{array}{l}\text { Morayo I. Atinmo dan } \\
\text { Samuel W. Jimba }\end{array}$ & 2002 & $\begin{array}{l}\text { Gender and authorship patterns in } \\
\text { an African Librarianship Journal, } \\
\text { 1991-1997 }\end{array}$ & $\begin{array}{l}\text { Karya individu lebih medominasi } \\
\text { daripada karya kolaborasi }\end{array}$ \\
\hline 2 & $\begin{array}{l}\text { Yazit, N dan } \\
\text { Zainab, A.N. }\end{array}$ & 2007 & $\begin{array}{l}\text { Publication Productivity of } \\
\text { Malaysian Authors and Institution } \\
\text { in LIS }\end{array}$ & $\begin{array}{l}\text { Karya individu lebih medominasi } \\
\text { daripada karya kolaborasi }\end{array}$ \\
\hline 3 & Warraich, N.F. & 2011 & $\begin{array}{l}\text { Pakistan Journal of Library \& } \\
\text { Information Science }\end{array}$ & $\begin{array}{l}\text { Karya individu lebih medominasi } \\
\text { daripada karya kolaborasi yang } \\
\text { ditulis dua, tiga atau lima penulis }\end{array}$ \\
\hline 4 & Singh, R. dan Misra, R. & 2013 & Iaslic Bulletin: A Bibliometric Study & $\begin{array}{l}\text { Karya individu lebih medominasi } \\
\text { dari pada karya kolaborasi yang }\end{array}$ \\
\hline
\end{tabular}




\begin{tabular}{|c|c|c|c|c|}
\hline & & & & ditulis dua, tiga, atau empat penulis \\
\hline 5 & Ghouse Modin M. dkk & 2013 & $\begin{array}{l}\text { Scientometric Analysis of } \\
\text { Contributions to the Journal } \\
\text { College and Research Libraries } \\
(1997-2011)\end{array}$ & $\begin{array}{l}\text { Karya individu lebih mendominasi } \\
\text { daripada karya kolaborasi yang } \\
\text { ditulis dua dan tiga penulis. } \\
\text { Derajat kolaborasi rata-rata } 0,57 \text {, } \\
\text { rata-rata artikel yang dihasilkan } \\
\text { setiap penulis adalah } 1,88\end{array}$ \\
\hline 6 & Roy, S.B. dan Basak, M. & 2013 & $\begin{array}{l}\text { Journal of Documentation : } \\
\text { a Bibliometric Study }\end{array}$ & $\begin{array}{l}\text { Karya individu lebih mendominasi } \\
\text { daripada karya kolaborasi. Derajat } \\
\text { kolaborasi } 0,510\end{array}$ \\
\hline 7 & $\begin{array}{l}\text { Rahayu, Rochani Nani } \\
\text { dan Nurhayati }\end{array}$ & 2013 & $\begin{array}{l}\text { Tingkat Kolaborasi dan } \\
\text { Produktivitas Pengarang Majalah } \\
\text { BACA Periode 1995-2000 }\end{array}$ & $\begin{array}{l}\text { Penulis individu lebih banyak jika } \\
\text { dibandingkan dengan penulis } \\
\text { yang berkolaborasi. Derajat } \\
\text { kolaborasi } 0,53\end{array}$ \\
\hline 8 & Panda, I; dkk & 2013 & $\begin{array}{l}\text { The Journal of Information Litarcy: } \\
\text { A Bibliometric Study }\end{array}$ & $\begin{array}{l}\text { Karya individu lebih mendominasi } \\
\text { daripada karya kolaborasi yang } \\
\text { ditulis dua, tiga, empat, maupun } \\
\text { enam penulis. }\end{array}$ \\
\hline 9 & $\begin{array}{l}\text { Simaki S., Geraei E dan } \\
\text { Zare-Farashbandi F }\end{array}$ & 2014 & $\begin{array}{l}\text { A study on scientific collaboration } \\
\text { and co-authorship patterns in } \\
\text { library and information science } \\
\text { studies in Iran between } 2005 \\
\text { and } 2009\end{array}$ & $\begin{array}{l}\text { Dari } 942 \text { artikel, sebanyak } 506 \\
\text { artikel (53,70\%) ditulis secara } \\
\text { individu dan } 436 \text { artikel ( } 46,30 \%) \\
\text { ditulis secara kolaborasi dua } \\
\text { orang atau lebih }\end{array}$ \\
\hline 10 & Mani, K. T. & 2014 & $\begin{array}{l}\text { Authorship Patterns and } \\
\text { Collaborative Research in } \\
\text { Malaysian Journal of Library and } \\
\text { Information Science, } 1996 \text { - } 2012\end{array}$ & $\begin{array}{l}\text { Karya individu lebih medominasi } \\
\text { daripada karya kolaborasi. Tingkat } \\
\text { kolaborasi } 0,64\end{array}$ \\
\hline
\end{tabular}

\subsection{Produktivitas Peneliti}

Produktivitas peneliti didefinisikan sebagai perbandingan antara hasil yang dicapai (jumlah artikel) dengan seluruh sumber daya yang digunakan (jumlah peneliti). Produktivitas peneliti terdiri atas beberapa output, antara lain, koleksi, temuan, database, paten, teknik, buku, dan makalah publikasi. Makalah publikasi merepresentasikan aspek penting dari produktivitas penelitian. Terdapat tiga cara yang dapat digunakan untuk mengetahui produktivitas peneliti, antara lain menghitung jumlah artikel yang dipublikasikan melalui database bibliometrik, melalui survei, dan menghitung makalah tertulis dan publikasi yang diperoleh dari self- constructed vita (Ynalvez dan Shrum, 2011).

Beberapa penelitian mengenai produktivitas penulis telah banyak dilakukan, dua di antaranya diuraikan pada Tabel 2. 
Tabel 2. Penelitian Produktivitas Penulis IPI

\begin{tabular}{|c|l|c|l|l|}
\hline No. & Penulis / Peneliti & Tahun & Judul & Hasil Penelitian \\
\hline 1 & Sutarsyah & 2014 & $\begin{array}{l}\text { Kajian profil artikel dan } \\
\text { produktivitas penulis pada warta } \\
\text { kebun raya }\end{array}$ & $\begin{array}{l}\text { Produktivitas peneliti KRB dari } \\
\text { tahun 2009 s.d. 2013 sebesar 0.21\% } \\
\text { (tergolong rendah, yaitu 0,21 } \\
\text { artikel/peneliti/tahun) } \\
\text { Produktivitas dan tingkat } \\
\text { kolaborasi penulis dalam karya } \\
\text { tulis ilmiah peneliti bidang zoologi, } \\
\text { Puslit Biologi-LIPI 2005-2010 } \\
\text { memiliki tingkat kolaborasi } \\
\text { sebesar 0,84. }\end{array}$ \\
\hline
\end{tabular}

\section{METODE}

Data yang digunakan dalam kajian ini adalah semua artikel bidang ilmu dokumentasi, informasi, dan perpustakaan yang terbit di Jurnal Visi Pustaka tahun 2000 - 2014. Jurnal Visi Pustaka dipilih sebagai bahan kajian karena jurnal tersebut merupakan media komunikasi ilmiah di antara para pustakawan ataupun peneliti untuk mempublikasikan dan memasyarakatkan hasil-hasil penelitian yang terkait dengan bidang dokumentasi, informasi, dan perpustakaan. Selain itu, sampai saat ini belum ada peneliti yang melakukan kajian menggunakan artikel yang dipublikasikan pada Jurnal Visi Pustaka.

Metode pengumpulan data pada kajian ini menggunakan dokumentasi, yakni data diperoleh melalui dokumen. Data produktivitas ilmiah diperoleh melalui pemeriksaan dan pencatatan terhadap semua artikel yang terkait dengan dokumentasi, informasi, dan perpustakaan yang dipublikasikan pada jurnal Visi Pustaka. Selanjutnya data dikelompokan berdasarkan jumlah artikel, frekuensi penulis, jenis kelamin penulis, produktivitas penulis, tingkat kolaborasi, dan instansi tempat kerja penulis. Keuntungan penelitian menggunakan dokumentasi ini menurut Usman dan Purnomo (1996) adalah biayanya relatif murah, serta waktu dan tenaga efisien.

Analisis data dilakukan dengan metode deskriptif, yakni dengan menggambarkan kondisi riil secara persentase berdasarkan jumlah artikel, frekuensi penulis, jenis kelamin penulis, produktivitas penulis, dan instansi tempat kerja penulis. Adapun untuk menentukan tingkat kolaborasi menggunakan metode Subramayan (1983), sebagi berikut.

$$
C=\frac{\mathrm{Nm}}{\mathrm{Nm}+\mathrm{Ns}}
$$

\section{Keterangan:}

$$
\begin{array}{ll}
\mathrm{C} & =\text { tingkat kolaborasi } \\
\mathrm{Nm} & =\text { total hasil penelitian yang dilakukan secara kolaborasi } \\
\mathrm{Ns} & =\text { total hasil penelitian yang dilakukan secara individu }
\end{array}
$$

Jika nilai $\mathrm{C}=0$, hal ini menunjukkan hasil penelitian pada bidang tersebut seluruhnya dilakukan secara individual. Apabila nilai C berkisar $0<0,50$ maka dapat disimpulkan bahwa hasil penelitian lebih banyak dilakukan secara individual dibandingkan dengan cara kolaborasi dan jika nilai C > 0,50 maka penelitian lebih banyak dilakukan secara kolaborasi. Apabila nilai $\mathrm{C}=1$ maka hasil penelitian seluruhnya dilakukan secara kolaborasi. 


\section{HASIL DAN PEMBAHASAN}

\subsection{Jumlah Artikel Visi Pustaka}

Jumlah artikel yang dimuat dalam Jurnal Visi Pustaka pada tahun 2000 - 2014, dapat dilihat pada Gambar 1.

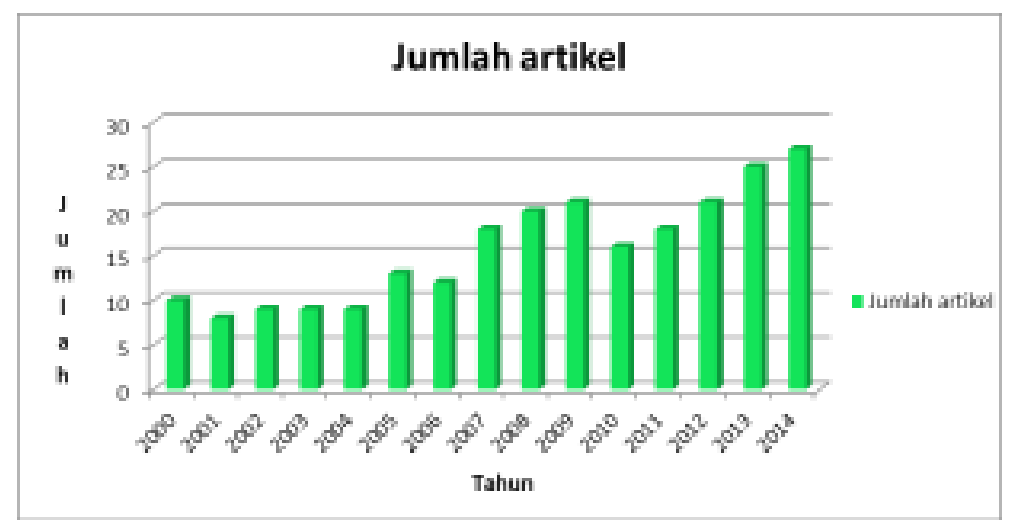

Gambar 1. Jumlah artikel Visi Pustaka2000 - 2014

Dari data Gambar 1, terlihat bahwa jumlah artikel yang dipublikasikan pada Jurnal Visi Pustaka pada tahun 2000-2014 sebanyak 236 artikel, dengan rata-rata publikasi sebanyak 15 artikel pertahun. Pada tahun 2007-2009 jumlah artikel publikasi ini mengalami peningkatan dari 18 artikel menjadi 21 artikel. Hal tersebut terjadi karena frekuensi terbit bertambah dari dua kali menjadi tiga kali dalam setahun, yaitu April, Agustus dan Desember. Peningkatan juga terjadi pada tahun 2012-2014, yaitu dari 21 artikel menjadi 27 artikel. Hal ini menunjukkan bahwa semakin banyak penulis yang aktif berbagi pengetahuan dengan cara menyebarluaskan hasil-hasil penelitian, ide serta hal-hal lain yang berkaitan dengan ilmu informasi dan perpustakaan melalui artikel Visi Pustaka.

Jumlah publikasi tertinggi terjadi pada tahun 2014, yaitu sebanyak 27 artikel (11,44\%). Adanya Perpres RI Nomor 71 Tahun 2013 (pengganti Perpres RI Nomor 47 Tahun 2007) mengenai kenaikan tunjangan fungsional pustakawan telah mendorong pustakawan untuk berlomba-lomba mendapatkan angka kredit melalui penerbitan karya ilmiah di jurnal guna kenaikan tunjangan fungsionalnya.

\subsection{Jumlah Penulis Artikel Visi Pustaka}

Untuk mengetahui jumlah penulis dalam artikel Visi Pustaka pada tahun 2000 - 2014 dapat dilihat pada Gambar 2. 


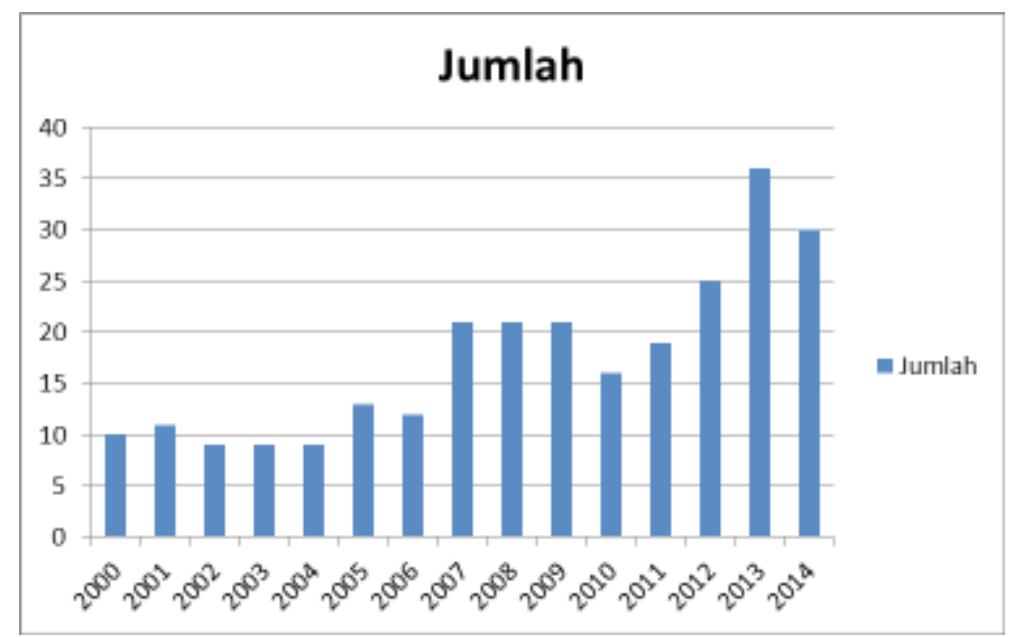

Gambar 2. Jumlah penulis dalam artikel Jurnal Visi Pustaka Tahun 2000 - 2014

Gambar 2 menunjukkan bahwa penulis yang berpartisipasi dalam Jurnal Visi Pustaka tahun 2000 - 2014 berjumlah 262 orang. Pada tahun 2002 - 2004 jumlah penulis tidak berubah dan merupakan jumlah penulis terendah dalam kurun waktu 15 tahun. Kondisi ini disebabkan oleh frekuensi penerbitannya masih dua kali dalam setahun sehingga jumlah artikel yang masuk juga sedikit dan belum adanya kolaborasi antar-penulis.

Jumlah penulis tertinggi dalam Visi Pustaka terjadi pada tahun 2013. Kondisi ini disebabkan bertambahnya frekuensi terbit, dari 2 kali menjadi 3 kali dalam setahun. Selain itu, adanya Perpres RI Nomor 71 Tahun 2013 mendorong pustakawan untuk membuat karya ilmiah yang dimuat di jurnal agar mendapatkan angka kredit guna kenaikan tunjangan fungsionalnya.

\subsection{Jenis Kelamin Penulis Artikel Visi Pustaka}

Berdasarkan jenis kelamin penulis artikel Jurnal Visi Pustaka tahun 2000 - 2014 dapat dilihat pada Gambar 3.

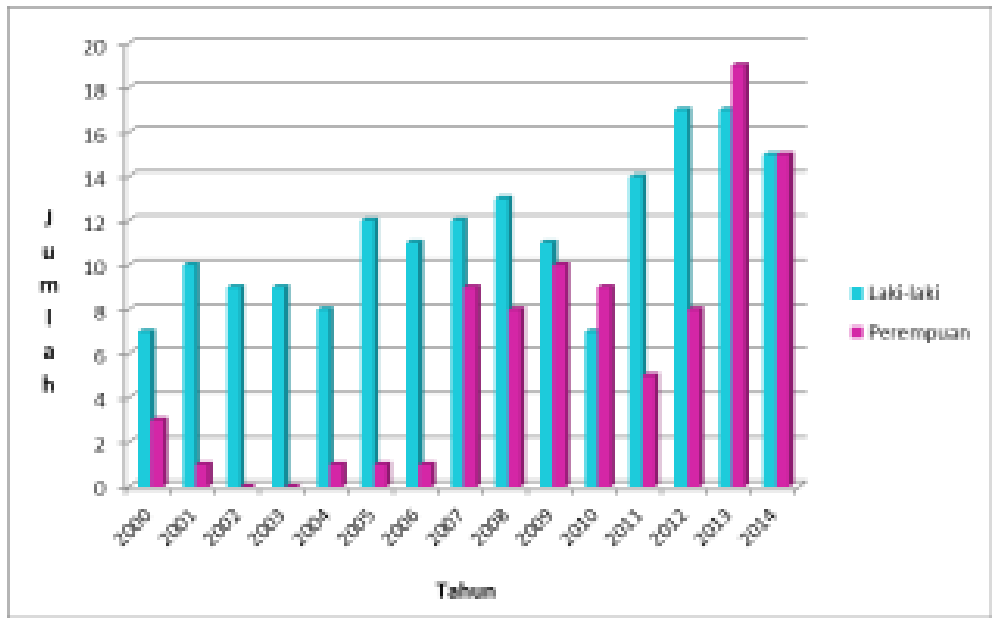

Gambar 3. Jenis kelamin penulis artikel Visi Pustaka tahun 2000 - 2014

Jumlah penulis artikel Visi Pustaka tahun 2000 - 2014 sebanyak 262 orang, terdiri atas lakilaki 172 orang (65,64\%) dan penerempuan 90 orang (34,36\%). Data ini menunjukkan bahwa secara umum, jumlah penulis laki-laki lebih banyak daripada penulis perempuan. Abramo et al. (2015) menjelaskan bahwa pada beberapa sektor ilmiah, perempuan bukan sebagai pihak inferior. 
Namun demikian, laki-laki masih mendominasi sebagai penulis pertama dan terakhir, sedangkan perempuan lebih sering menjadi penulis tunggal dalam suatu makalah. Produktivitas penulis perempuan lebih rendah dibandingkan laki-laki karena alasan pribadi, seperti pernikahan dan tugas mengasuh anak.

Brooks et al. (2014) menjelaskan bahwa terdapat perbedaan jumlah publikasi antara laki-laki dan perempuan. Laki-laki menghasilkan publikasi lebih banyak daripada perempuan, terutama dalam bidang akuntansi, manajemen informasi, dan jurnal-jurnal strategi.

Kondisi tersebut serupa dengan hasil Analisis Abstrak Widyakarya Nasional Pangan dan Gizi Tahun 2012 yang menunjukkan bahwa dari 45 judul makalah yang ditulis oleh 110 penulis, sebanyak 66 penulis laki - laki (60\%) dan 44 penulis perempuan (40,00\%). Penelitian Rochani Nani Rahayu dan Eti Budiartini yang berjudul Kolaborasi Penulis pada Prosiding Hasil Penelitian Terbaik 2012 Badan Penelitian dan Pengembangan Kelautan dan Perikanan yang dilakukan pada 2014 menunjukkan bahwa dari 101 penulis yang berpartisipasi dalam seminar tersebut, sebanyak 59 penulis laki-laki $(58,41 \%)$ dan 42 penulis perempuan $(41,59 \%)$. Berdasarkan hasil kajian Prosiding Seminar Nasional Matematika Universitas Parahiyangan 2008 - 2011 diketahui bahwa sebanyak 210 judul makalah, ditulis oleh 193 penulis laki - laki (58,84\%) dan 135 penulis perempuan (41,16\%) (Rahayu dan Hendiyarto, 2014).

\subsection{Tingkat Kolaborasi Penulis Artikel Visi Pustaka}

Tingkat kolaborasi penulis VISI PUSTAKA2000-2014 dapat dilihat pada Gambar 4 di bawah ini.

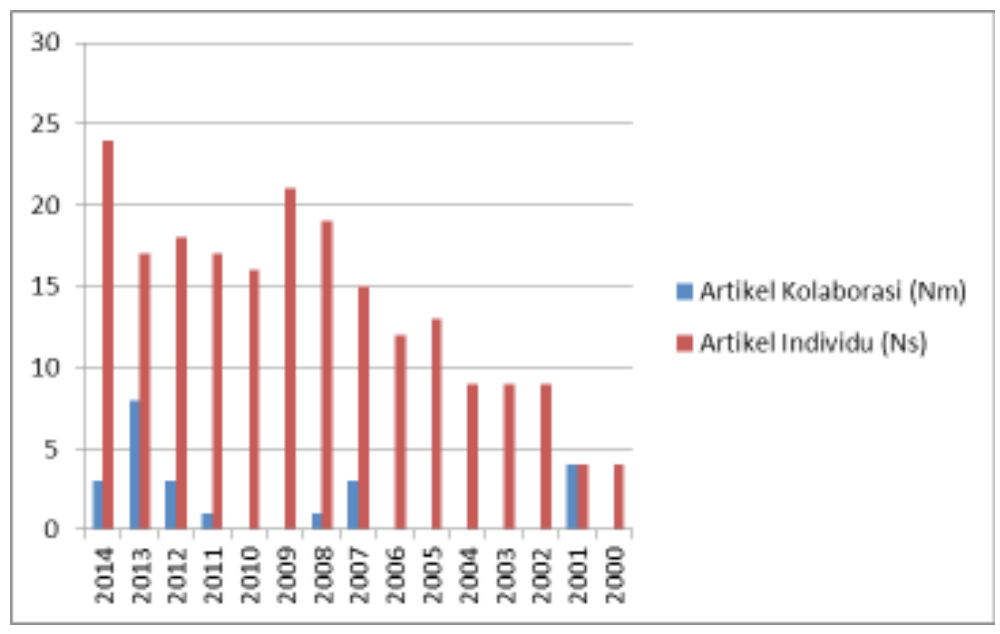

Gambar 4. Tingkat kolaborasi penulis Visi Pustaka tahun 2000 - 2014

Jumlah artikel jurnal Visi Pustaka tahun 2000 - 2014 adalah 236 artikel, yang terdiri atas karya kolaborasi 23 artikel dan karya individu sebanyak 213 artikel. Periode 2002 - 2006 dan 2009 - 2010 tidak ada karya kolaborasi. Secara umum, karya kolaborasi Visi Pustaka 2000-2014 lebih sedikit jika dibandingkan dengan karya individu. Penulis cenderung menghasilkan karya individu karena angka kredit yang dapat diperoleh lebih besar dibanding karya kolaborasi. Menurut Peraturan Kepala Perpustakaan Nasional Republik Indonesia Nomor 2 Tahun 2008 tentang Jabatan Fungsional Pustakawan dan Angka Kreditnya, karya individu mendapat persentase angka kredit 100\%, sedangkan berkolaborasi ada pembagian persentase angka kredit, yaitu penulis pertama sebesar $60 \%$, sedangkan penulis kedua dan seterusnya sebesar $40 \%$. 
Menurut Sutarsyah (2014), karya individu yang lebih banyak daripada karya kolaborasi dimungkinkan karena tingkat kolaborasi bervariasi antar-disiplin ilmu, serta dipengaruhi oleh berbagai faktor seperti lingkungan riset, demografi, dan disiplin ilmu.

Hasil penelitian ini menunjukkan kesamaan dengan hasil penelitian terdahulu, di antaranya yang dilakukan oleh Rochani Nani Rahayu dan Nurhayati (2013) yang berjudul Tingkat Kolaborasi dan Produktivitas Pengarang Majalah BACA Periode 1995 - 2000 diketahui tingkat kolaborasi penulis tergolong rendah, yaitu 0,153. Demikian pula Morayo I. Atinmo dan Samuel W. Jimba (2002) dalam artikel tentang pola kepengarangan pada African Librarianship Journal 1991-1997 menunjukkan bahwa dari sejumlah 95 artikel penelitian yang ditulis oleh 118 orang, 83,20\% ditulis secara individu dan sisanya 16,80\% ditulis secara berkolaborasi. Mani, K.T., dalam artikel yang berjudul Authorship Patterns and Collaborative Research in Malaysian Journal of Library and Information Science, 1996 - 2012 yang dimuat dalam Library Philosophy and Practice (e-journal) 2014. Paper 1177 menyebutkan bahwa dari sejumah 279 artikel dan 575 pengarang yang diteliti diketahui sebanyak 180 artikel (64,526\%) ditulis secara berkolaborasi dan sisanya 99 judul $(35,484 \%)$ ditulis secara individu.

\subsection{Frekuensi Kolaborasi Penulisan Visi Pustaka}

Pola kepengarangan penulisan yang ditulis secara individu berjumlah 213 judul, artikel yang ditulis 2 orang berjumlah 36 artikel, dan artikel yang ditulis oleh $>2$ orang berjumlah 13 judul. Frekuensi kolaborasi penulisan terbanyak tercatat 4 kali yang dilakukan oleh Abdul Rahman Saleh dari IPB dan Rochani Nani Rahayu dari PDII. Berikutnya, frekuensi kolaborasi penulisan sebanyak 2 kali dilakukan oleh 4 orang (B. Mustafa, Joko Santoso, Tupan, dan Wahid Nashihudin). Adapun frekuensi kolaborasi penulisan sebanyak satu kali dilakukan oleh 33 orang (Abdurrahman Prasetyadi, Alfa Husna, Anita Nusantari, Arwan Subakti, D.W. Ari Nugroho, Dian Nurmalasari, Dwi Dian Nusantari, Endang Purnomo Giri, Ety Budiartin, Fiqru Mafar, Heni Linggowati Holbrook, Ilham Prisgunanto, Janti G. Sujono, Laksmi, Maryono, Meuthia Rachmaniah, Nining, Novalinda, Nurhayati, Pergola Irianti, Ratnaningsih, Siti Anisah, Sri Junandi, Sri Palupi, Subagyo, Sungkowo Rahardjo, Suryadiputra Liawatimena, Teguh Purwanto, Tim Inpres, Titik Hermini, Wanda Listiani, Yaniasih, dan Yusalina. Secara lengkap data frekuensi kolaborasi penulisan artikel tertera dalam Tabel 3.

Tabel 3. Frekuensi Kolaborasi Penulis Visi Pustaka Tahun 2000 - 2014

\begin{tabular}{|l|c|c|c|c|c|}
\hline \multirow{2}{*}{ Nama Penulis } & \multicolumn{3}{|c|}{ Pola Kepengarangan } & Jumlah & $\begin{array}{c}\text { Frekuensi } \\
\text { Kolaborasi } \\
\text { Penulisan }\end{array}$ \\
\cline { 2 - 4 } & 1 Penulis & 2 Penulis & > 2 Penulis & & \\
\hline Abdul Rahman Saleh & 2 & 1 & 3 & 6 & 4 \\
Abdurrahman Prasetyadi & 0 & 1 & 0 & 1 & 1 \\
Adi Prasetyawan & 1 & 0 & 0 & 1 & 0 \\
Adin Bondar & 2 & 0 & 0 & 2 & 0 \\
$\ldots \ldots . . .$. & $\ldots$ & $\ldots$ & $\ldots$ & $\ldots$ & $\ldots$ \\
$\ldots . . . .$. & $\ldots$ & $\ldots$ & $\ldots$ & $\ldots$ & $\ldots$ \\
Zeni Istiqomah & 1 & 0 & 0 & 1 & 0 \\
\hline Jumlah & 213 & 36 & 13 & 262 & \\
\hline
\end{tabular}

\subsection{Peringkat Produktivitas Penulis Visi Pustaka}

Peringkat produktivitas penulis Visi Pustaka tahun 2000 - 2014 berdasarkan Tabel 4 
menunjukkan 7 peringkat produktivitas penulis dengan jumlah karya tulis yang dihasilkan pada peringkat pertama masing-masing 16 judul, peringkat kedua 6 judul, peringkat ketiga 5 judul, peringkat keempat 4 judul, peringkat kelima 3 judul, peringkat keenam 2 judul, dan peringkat ketujuh 1 judul. Di samping itu, jumlah penulis yang menduduki peringkat pertama 2 orang, peringkat kedua 2 orang, peringkat ketiga 3 orang, peringkat keempat 4 orang, dan peringkat kelima 11 orang. Secara keseluruhan, jumlah penulis yang menduduki posisi peringkat 1 s.d.5 adalah 22 orang.

Tabel 4. Peringkat Produktivitas Penulis Visi Pustaka Tahun 2000-2014

\begin{tabular}{|l|c|c|c|}
\hline Nama Penulis & $\begin{array}{c}\text { Karya Tulis } \\
\text { (Judul) }\end{array}$ & $\begin{array}{c}\text { Persentase } \\
\text { (\%) }\end{array}$ & $\begin{array}{c}\text { Peringkat } \\
\text { Produktivitas }\end{array}$ \\
\hline Sulistyo-Basuki & 16 & 6,11 & 1 \\
B. Mustafa & 16 & 6,11 & 1 \\
Abdul Rahman Saleh & 6 & 2,29 & 2 \\
Hendro Wicaksono & 6 & 2,29 & 2 \\
$\ldots \ldots .$. & $\ldots$ & $\ldots$ & $\ldots$ \\
$\ldots . .$. & $\ldots$. & $\ldots$ & $\ldots$ \\
Zeni Istiqomah & 1 & 0,38 & 7 \\
\hline Jumlah & 262 & 100 & \\
\hline
\end{tabular}

\subsection{Instansi Tempat Kerja Penulis Visi Pustaka}

Afiliasi tempat penulis bekerja merupakan salah satu indikator keberhasilan bagi instansi dalam mendorong sivitas di lingkungannya untuk menulis di jurnal ilmiah, termasuk di Jurnal Visi Pustaka. Dari Tabel 5 terlihat sebanyak 68 instansi yang berpartisipasi dalam penulisan artikel Visi Pustaka. Tingkat partisipasi tertinggi diduduki oleh perpustakaan perguruan tinggi, yaitu sebanyak 153 (58,39\%). Selanjutnya, diikuti oleh perpustakaan khusus/lembaga sebanyak 50 (19,08\%); perpustakaan umum sebanyak 38 (14,50\%); perpustakaan yayasan/perusahaan sebanyak 10 (3,82\%), perpustakaan lain-lain sebanyak 6 (2,29\%); dan perpustakaan sekolah (SD/SMP/SMA/ SMK) sebanyak 5 (1,91\%). Kondisi ini dapat diinterpretasikan bahwa perpustakaan perguruan tinggi memiliki tingkat partisipasi yang relatif jauh lebih tinggi jika dibandingkan dengan perpustakaan khusus/lembaga, perpustakaan umum, perpustakaan yayasan/perusahaan, perpustakaan lain-lain, dan perpustakaan sekolah. Hal ini dikarenakan adanya Surat Edaran Direktorat Jenderal Pendidikan Tinggi Nomor 152/E/T/2012 mengenai publikasi karya ilmiah sebagai persyaratan lulus program sarjana, program magister, dan program doktor.

Tabel 5. Instansi Tempat Bekerja Penulis Visi Pustaka Tahun 2000 - 2014

\begin{tabular}{|l|c|c|}
\hline Jenis instansi & Jumlah/Frekuensi & Persentase (\%) \\
\hline Perpustakaan umum & 38 & 14,50 \\
Perpustakaan khusus/lembaga & 50 & 19,08 \\
Sekolah (SD,SMP,SMA/SMK) & 5 & 1,91 \\
Perpustakaan Perguruan Tinggi & 153 & 58,39 \\
Perusahaan/Yayasan & 10 & 3,82 \\
Lain-lain & 6 & 2,29 \\
\hline Jumlah & 262 & 100 \\
\hline
\end{tabular}


Dari Tabel 6 terlihat bahwa ada lima besar instansi yang produktif sebagai penyumbang artikel Visi Pustaka tahun 2000 - 2014. Urutan pertama diduduki oleh Intitut Pertanian Bogor. Urutan berikutnya, yaitu Perpustakaan Nasional RI, Universitas Indonesia, Pusat Dokumentasi dan Informasi Ilmah - LIPI, dan Universitas Gadjah Mada. Kondisi ini dapat diinterpretasikan bahwa IPB merupakan instansi yang memiliki penulis paling produktif menulis di Jurnal Visi Pustaka. Kondisi ini terjadi karena adanya Surat Edaran Rektor IPB Nomor 13947/I3.10/KM/2011 mengenai kewajiban publikasi karya ilmiah bagi mahasiswa program pascasarjana S2 dan S3 di IPB.

Tabel 6. Instansi Penulis Paling Produktif di Jurnal Visi Pustaka Tahun 2000 - 2014

\begin{tabular}{|l|c|c|}
\hline Instansi & Frekuensi & Persentase (\%) \\
\hline IPB & 38 & 14,50 \\
Perpustakaan Nasional RI & 32 & 12,21 \\
UI & 29 & 11,07 \\
PDII-LIPI & 21 & 8,01 \\
UGM & 19 & 7,25 \\
\hline Jumlah & 139 & 53,04 \\
\hline
\end{tabular}

Dari Tabel 7 terlihat bahwa status instansi tempat penulis bekerja tidak hanya instansi milik pemerintah, tetapi juga penulis yang bekerja pada instansi swasta. Penulis dari instansi pemerintah mendominasi (212 artikel atau 80,91\%) dibanding penulis dari instansi swasta (50 artikel atau 19,09\%) dalam penulisan artikel pada Jurnal Visi Pustaka. Kondisi ini terjadi karena adanya dorongan kenaikan tunjangan fungsional pustakawan bagi pustakawan PNS.

Tabel 7. Status Instansi Penulis Jurnal Visi Pustaka Tahun 2000 - 2014

\begin{tabular}{|l|c|c|}
\hline Status & Jumlah/frekuensi & Persentase (\%) \\
\hline Pemerintah & 212 & 80,91 \\
Swasta & 50 & 19,09 \\
\hline Jumlah & 262 & 100 \\
\hline
\end{tabular}

\section{KESIMPULAN}

Berdasarkan hasil dan pembahasan di atas, dapat disimpulkan sebagai berikut.

a) Artikel yang dipublikasikan ada sebanyak 236 artikel. Publikasi tertinggi terjadi pada tahun 2014 dan terendah pada tahun 2001, dengan rata-rata publikasi sebanyak 16 artikel per tahun.

b) Jumlah penulis seluruhnya ada 262 orang penulis. Penulis yang memublikasikan artikelnya paling banyak terjadi pada tahun 2013 (36 orang 11,49\%) dan terendah terjadi pada tahun 2002 - 2004 (9 orang 3,45\%).

c) Dari 262 penulis pada butir b), jumlah penulis laki-laki (172 orang 65,64\%) lebih banyak dibanding dengan penulis perempuan (90 orang 34,36\%).

d) Tingkat kolaborasi penulis tertinggi sebesar 32\% terjadi pada tahun 2013 dan terendah (0 \%) terjadi pada tahun 2000, 2002 - 2006, dan 2009 - 2010 , dengan rata-rata tingkat kolaborasi pertahunnya sebesar 9,7\%. Hal ini menunjukkan bahwa jumlah artikel yang ditulis secara individu lebih banyak dibandingkan artikel yang ditulis secara kolaborasi.

e) Terdapat 68 instansi yang berpartisipasi dalam penulisan artikel pada Jurnal Visi Pustakapada 
periode tersebut. Perpustakaan perguruan tinggi memiliki tingkat partisipasi yang paling dominan, yaitu sebanyak 153 kali (58,39\%) dibanding dengan tingkat partisipasi perpustakaan khusus/lembaga 50 kali (19,08\%), perpustakaan umum 38 kali (14,50\%), perpustakaan yayasan/perusahaan 10 kali (3,82\%), perpustakaan lain-lain 6 kali (2,29\%), dan perpustakaan sekolah (SD/SMP/SMA/ SMK) 5 kali (1,91\%).

f) Terdapat 7 peringkat produktivitas penulis dengan jumlah karya tulis yang dihasilkan masingmasing: peringkat pertama 16 judul, peringkat kedua 6 judul, peringkat ketiga 5 judul, peringkat keempat 4 judul, peringkat kelima 3 judul, peringkat keenam 2 judul, dan peringkat ketujuh 1 judul. Sulistyo-Basuki dan B. Mustofa menduduki peringkat pertama masing-maing dengan jumlah artikel 16 judul.

g) Terdapat lima besar instansi paling produktif sebagai penyumbang artikel pada Jurnal Visi Pustaka pada periode tersebut. IPB merupakan instansi penyumbang artikel paling produktif (38 artikel 14,38\%), dibanding dengan Perpustakaan Nasional RI (32 artikel 11,45\%), Universitas Indonesia (29 artikel 12,60\%), Pusat Dokumentasi dan Informasi Ilmah-LIPI (21 artikel 8,02\%), dan Universitas Gadjah Mada (19 artikel 6,11\%).

h) Terdapat 262 artikel yang dipublikasikan pada Jurnal Visi Pustaka pada periode tersebut. Dari jumlah tersebut, penulis dari instansi pemerintah lebih mendominasi (212 artikel 80,91\%) dibanding penulis dari instansi swasta (50 artikel 19,09\%).

\section{DAFTAR PUSTAKA}

Abramo, Giovani; Ciriaco Andrea D’Angelo; Gianluca Murgiac. 2015. “Should The Research Performance of Scientists Bedistinguished by Gender?. Journal of Informetrics, 9: 25-38.

Brooks, Chris; Evelyn M. Fenton; James T. Walker. 2014. "Gender and The Evaluation of Research. Research Policy, 43: 990-1001.

Mamdapur, Ghouse Modin, et al. 2013. "Scientometric Analysis of Contributions to The Journal College and Research Libraries (1997-2011)". Library Philosophy and Practice (e-Journal). Paper 905. (http://digitalcommons.unl.edu/libphilprac/905, diakses 12 Juni 2015).

Mani, Kotti Thavamani. 2014. "Authorship Patterns and Collaborative Research in Malaysian Journal of Library and Information Science, 1996 - 2012”. Library Philosophy and Practice (e-Journal). Paper 1177. DOI: 10.4103/2277-9531.139681. (http://digitalcommons.unl.edu/libphilprac/1177, diakses 12 Juni 2015).

Maryono dan Sri Junandi. 2012. "Indonesian Journal of Chemistry 2007 - 2011: Analisis Kolaborasi dan Institusi”. Visi Pustaka, 14 (3).

Morayo I. Atinmo dan Samuel W. Jimba. 2002. "Gender and Authorship Patterns in an African Librarianship Journal, 1991 1997”. Library Review, 15(9): 458 - 463.

Panda, I; Maharana, B; Chhatar, D.C. 2013. “The Journal of Information Litarcy: A Bibliometric Study”. International Journal Scientific and Research Publication, 3 (3), (http://www.ijsrp. org/research-journal-0313.php, diakses 12 Juni 2015).

Peraturan Kepala Perpustakaan Nasional Republik Indonesia Nomor 2 Tahun 2008 Tentang Petunjuk Teknis Jabatan Fungsional Pustakawan dan Angka Kreditnya.

Peraturan Presiden Republik Indonesia Nomor 47 Tahun 2007 Tentang Tunjangan Jabatan Fungsional Pustakawan.

Peraturan Presiden Republik Indonesia Nomor 71 Tahun 2013 Tentang Tunjangan Jabatan Fungsional Pustakawan.

Purnomowati, Sri dan Yuliastuti, Rini. 2000. Pola Kepengarangan dalam Majalah BACA Tahun 1974 1999. BACA: Jurnal Dokumentasi dan Informasi, 25 (1-2).

Rahayu, Rochani Nani dan Eti Budiartini. 2014. "Kolaborasi Penulis pada Prosiding Hasil Penelitian Terbaik 2012 Badan Penelitian dan Pengembangan Kelautan dan Perikanan”. Laporan Penelitian. Jakarta: Pusat Dokumentasi dan Informasi Ilmiah - LIPI.

Rahayu, Rochani Nani dan Hendiyarto Putroutomo. 2014. "Kajian Prosiding Seminar Nasional Matematika Universitas Parahiyangan 2008-2011”. Laporan Penelitian. Jakarta: Pusat Dokumentasi dan Informasi Ilmiah - LIPI.

Rahayu, Rochani Nani dan Nurhayati. 2013. Tingkat Kolaborasi dan Produktivitas Pengarang Majalah 
BACA Periode 1995-2000: Laporan penelitian. Jakarta: Pusat Dokumentasi dan Informasi Ilmiah LIPI.

Rahayu, Rochani Nani. 2013. “Analisis Abstrak Widyakarya Nasional Pangan dan Gizi X Tahun 2012”. Laporan Penelitian. Jakarta: Pusat Dokumentasi dan Informasi Ilmiah - LIPI.

Roy, Sanku Bilas dan Basak, Moutusi. 2013. “Journal of Documentation: a Bibliometric Study”. Library Philosophy and Practice (e-Journal). Paper 945. (http://digitalcommons. unl.edu/libphilprac/ 945, diakses 12 Juni 2015).

Simaki S; Geraei E; Zare-Farashbandi F. 2014. "A Study on Scientific Collaboration and Co- $\quad$ Authorship Patterns in Library and Information Science Studies in Iran Between 2005 and 2009”. J. Educ. Health Promot. Aug 28;3:99. DOI: 10.4103/2277-9531.139681.

Singh, Rakhi dan Misra, Rajani. 2013. "Iaslic Bulletin: A bibliometric Study”. IASLIC Buletin, 2 (4): 402 4010. (www.spoars.org/journal/sites/default/files/v2n4p5.pdf., diakses 12 Juni 2015).

Subramanyan, K. 1983. "Bibliometric Studies of Research Collaboration: a Review”. Journal of Information Science, 6: 33-38.

Surat Edaran Direktorat Jenderal Pendidikan Tinggi Nomor 152/E/T/2012 Mengenai Publikasi Karya Ilmiah.

Surat Edaran Rektor IPB Nomer 13947/I3.10/KM/2011 Tentang Publikasi Mahasiswa Pascasarjana IPB.

Sutarsyah. 2014. "Kajian Profil Artikel dan Produktivitas Penulis pada Warta Kebun Raya”. VISI PUSTAKA. 16 (3): 230-234.

Usman, Husaini dan Purnomo Setiadi Akbar.1996. Metodologi Penelitian Sosial. Jakarta: Bumi Aksara.

Warraich , N.F. 2011. "Pakistan Journal of Library and Information Science: A bibliometric Analysis". Pakistan Journal of Library \& Information Science, 12 p1. (http://connection.ebscohost. com/c/articles/83530130/pakistan-journal-library-information-science-bibliometric-analysis, diakses 12 Juni 2015).

Yazit, N dan Zainab, A.N. 2007. "Publication Productivity of Malaysian Author and Institution in LIS". Malaysian Journal of Library \& Information Science, 12(2): 35-55.

Ynalvez, Marcus Antonius dan Wesley M. Shrum. 2011. "Professional Networks, Scientific Collaboration, and Publication Productivity in Resource-Constrained Research Institutions in a Developing Country”. Research Policy, 40: 204-216. 